\title{
Administration and Control Optimization for the Alliance Project for Natural Disaster Logistics Management: The Application of Soft Systems Methodology at the Directorate of Social Protection for Natural Disaster Victims
}

\author{
Achmad Fauzi ${ }^{1 *}$, Deddi Nordiawan ${ }^{1}$ \\ ${ }^{1}$ Faculty of Economics and Business, Universitas Indonesia, Depok 16424, Indonesia \\ ${ }^{*}$ Corresponding Author: trezepiero82@gmail.com
}

\begin{abstract}
The irregularities in the number, timing, and location of requests for logistical assistance for disasters are features that must be addressed by existing disaster-management systems ${ }^{1}$. Furthermore, a disaster-logistics-management system also has the important and critical objectives of victim survival and using limited resources efficiently. For the Directorate of Social Protection for Natural Disaster Victims (Perlindungan Sosial Korban Bencana Alam) (Directorate of PSKBA), the logistics-management administration fully depends on an alliance project with the local government. In its current implementation, the logistics-management administration operated by the PSKBA Directorate has several problems in several activity areas, such as administration, distribution, reporting, monitoring, evaluation, and other critical activities. Using the soft system methodology (SSM) and literature developed by several researchers ${ }^{2,3,4}$, this research determined that these problems can be solved by producing several agreements with the related parties at the Directorate of PSKBA in order to optimize the processes of administration and control for disaster logistics inventory.
\end{abstract}

Keywords: Inventory; Natural Disaster Logistics; Public Sector; Administration; Control; Soft Systems Methodology; Alliance.

\section{INTRODUCTION}

Geographically, Indonesia is located between the Eurasian and Indo-Australian plates, which are moving at a speed of $52 \mathrm{~mm} /$ year, which means that Indonesia is a country prone to disaster events ${ }^{18}$. The official data released by the National Disaster Management Agency (Badan Nasional Penanggulangan Bencana) (BNPB) shows that during the year 2016, up to November, there was a total of 2,171 events that affected 2,770,814 people. Given the high number of disaster occurrences and impacts, the government is required to be able to provide disastermanagement services quickly, accurately, and reliably. One form of disaster management in the first phase of a disaster event is the provision of emergency-response logistics to alleviate the burden of the affected victims. The irregularities in the number, timing, and location of requests for disaster logistics assistance make this an interesting phenomenon that must be addressed by existing disaster-management systems ${ }^{1}$.

The Directorate of Social Protection for Natural Disaster Victims (Perlindungan Sosial Korban Bencana Alam) (Directorate of PSKBA) is a directorate under the Directorate General of Social Protection and Social Security (Ditjen Linjamsos), in the Ministry of Social Affairs of the Republic of Indonesia (Kemensos RI), whose main duty and function is providing disaster victims with social services. The PKSBA Directorate is one of the parties that has responsibility for disaster management. In order to achieve effective, efficient, optimal, transparent, and accountable disaster logistics management, the PKSBA Directorate is obliged to carry out the administration and control of the logistics inventory. In its current implementation, the administration and logistics control by the Directorate of PSKBA has several problems ${ }^{5}$. The weaknesses of the inventory and control activities in the Directorate of PSKBA reveal a complexity in the system of administration and control over the existing supply of disaster logistics.

\section{LITERATURE REVIEW}

Disaster and Disaster Logistics Management

Disasters are disruptions that physically affect the system as a whole, and threaten the priorities and goals of the 
system itself ${ }^{6}$. The irregularities and uncertainties about the types of disasters, the times of incidents, the occurrence, the numbers of victims, and the types of assistance required are challenges in the management of disaster logistics ${ }^{1,6,7}$ and play an important role in the success of disaster management ${ }^{6}$. In order to improve the logistics management of disasters, one needs to understand the difference between the characteristics of disaster logistics and the characteristics of the company's inventory in general ${ }^{8}$.

There are several challenges in the implementation of disaster logistics, which are a lack of recognition of the importance of disaster logistics, a lack of professional staff, a lack of technology, a lack of institutional learning, and a lack of collaboration ${ }^{4}$. On these challenges, five strategies are proposed for improving disaster logistics management, which are creating communities for disaster-logistics professionals, investing in standardized training and certification, focusing on performance measurement, communicating the importance of disaster logistics management, and developing solutions for the use of flexible technology ${ }^{4}$. In supply-chain activities, handling the coordination of disaster logistics among the parties involved is often difficult even though they share the same goals ${ }^{9}$. The achievement of coordination in the disaster-management sector is important for achieving the two interrelated objectives of victim survival and the efficient use of limited resources ${ }^{10}$.

\section{Management Control and Alliance}

Internal control is a process designed to provide reasonable assurance about the achievement of goals related to operations, reporting, and compliance ${ }^{11}$. While the Committee of Sponsoring Organizations of the Treadway Commission (COSO) defines internal control as a process influenced by boards of directors, management, and other personnel that seek to achieve objectives in the following categories: the effectiveness and efficiency of operations, the reliability of financial reporting, and compliance with applicable laws and regulations ${ }^{3}$.

There are differences in management-control systems related to the selection of corporate strategy due to the policy of managers to choose to exercise direct supervision or delegate other aspects to subordinates ${ }^{12}$. Furthermore, the model used to develop the hypothesis consists of four concepts: limited attention from managers, strategic uncertainty, interactive management control, and organizational learning ${ }^{12}$. In the implementation of disaster-logistics-management activities, the Directorate of PSKBA and social agencies in the provinces and regencies/municipalities are partners due to their interdependence. It is argued that as the level of organizational dependence increases, the coordination levels and the impact on the coordination of output units will also increase significantly ${ }^{14}$. In order to ensure effective partnerships are established, the partnerships need to manage the risks ${ }^{2}$.

\section{RESEARCH METHOD}

Disaster-logistics-management activities are a series of a human activities that are suitable for analysis using the soft system methodology (SSM). SSM was born based on the basic idea that the situation we are observing or meticulously documenting is an all-encompassing human-activity system in which we can choose one or several relevant human-activity systems to be compared and discussed with the real world in order to generate ideas for purposeful activities, which will further become the basis for action taken in the real world ${ }^{8}$. The approach using SSM method consists of seven standard cycle stages that are grouped into two areas, namely the real-world system and real-thinking system ${ }^{8}$. Furthermore, in practice, there are several modifications cycles, but these are still based on the standard cycle ${ }^{8}$. This research will use SSM modification cycle with the four recommended stages ${ }^{15}$.

\section{DISCUSSIONS}

After deepening their understanding of the existing problems through interviews and document reviews, the author collated all the information obtained into the following rich picture (Figure 1).

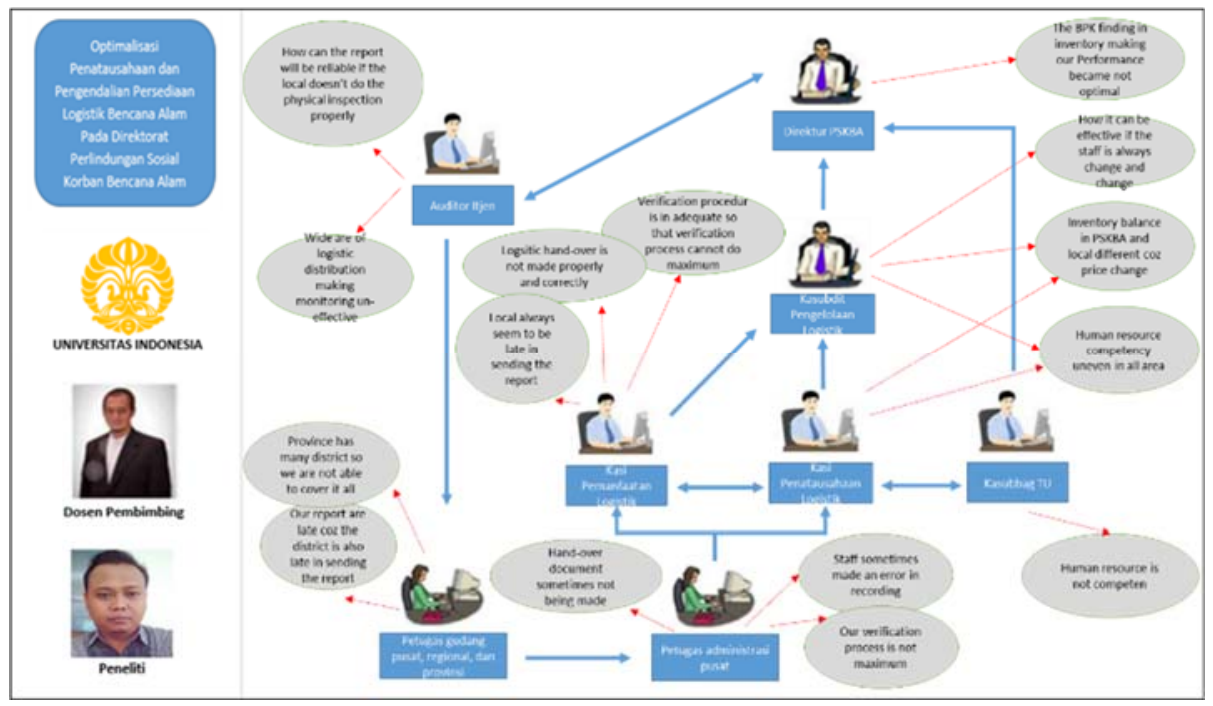


Figure.1. Rich Picture of the Situation and Problems of Logistics Management at the Directorate PSKBA

\section{Conceptual Model 1}

Root definition number 1 (RD1) is related to strengthening the local government's level of understanding about disaster logistics management. Under the environmental conditions of interorganizational partnerships such as this, it is argued that staffing and training appointments are an important measure used to regulate and standardize the partners' behavior; by having proper staff-appointment procedures, the partners will be in a better position to select the person who matches expectations ${ }^{2}$. Furthermore, in controlling the interorganizational behavior of mutual partners, one mechanism that can be used is the development of policies and procedures that can be included as part of a partnership contract, which contains details of certain restrictions on behavior as well as rewards ${ }^{2}$. It is also maintained that, in order to foster a sense of responsibility in the execution of tasks, management must create appropriate performance measurements, incentives, and rewards ${ }^{3}$. In addition, improving interregional coordination in the disbursement of disaster logistics when a disaster or emergency response occurs is a key factor in achieving effectiveness and efficiency, as coordination in the mitigation activities for a disaster is crucial for achieving the two interrelated objectives of victim survival and the efficient use of limited resources ${ }^{10}$.

In relation to the fact that some local governments have not been effective in the use of the SIMLOG application, it is believed that, despite the complexity in the logistics management of humanity, manual processes still dominate, so that the availability of information, reporting, and learning cannot be effective ${ }^{4}$. The effectiveness of the wide and simultaneous use of SIMLOG applications requires a joint commitment between the Directorate of PSKBA and the local governments.

Based on the considerations in RD1, the PQR formula (i.e., do P, by Q in order to achieve R) is as follows: strengthening the level of understanding of disaster logistics management with the local government $(\mathrm{P})$, through the design, with the local government, of a memorandum of understanding (Q), to optimize disaster logistics management activities at the Directorate of PSKBA (R). The CATWOE analysis (customer, actor, transformation, weltanschauung [worldview], owner, and environment) and conceptual model are shown in Table 1 and Figure 2, respectively.

From the results of the discussion on the conceptual model for strengthening the actors' understanding of disaster logistics management, the actors agree on several matters: the head of the logistics-utilization section and the head of the logistics-administration section will propose the early initiation of accepting the importance of developing logistics and a logistics-management agreement with the local government; the head of the subdirectorate for disaster logistics management will review the proposed input from the heads of sections, which will then be forwarded to the director; and they will form a team with the competent parties to formulate a draft memorandum of understanding when instructed to do so.

\section{Conceptual Model 2}

Root definition number 2 (RD2) is related to improving staff competency improvement, and improving the effectiveness of monitoring and evaluation. The lack of competence and knowledge of disaster-logisticsmanagement personnel can be seen from the frequent occurrence of errors in recording or inputting the numbers of goods. Regarding this matter, it is argued that the difficulties in recording are due to lack of technical guidance on asset management ${ }^{16}$. It is also believed that the standardization of training and certification will help to build a common view of common processes, and foster professionalism and collaboration ${ }^{4}$. In addition, the government should ensure that the inventory-control functions are only handled by competent and trained personnel ${ }^{17}$. Creating a professional logistics community will enable humanitarian logistics managers to share their knowledge and experience, and will create a robust channel for dealing with all stakeholders ${ }^{4}$.

In monitoring and supervising the implementation of tasks and functions of logistics personnel, the Directorate of PSKBA should have a strategy in order to overcome these problems. Organizations should select, develop, and conduct evaluations on an ongoing or separate basis to oversee or gain confidence in whether internal-control components are functioning ${ }^{3}$. In addition, there is a strategic issue related to disaster logistics management in that it is full of uncertainty about the outcomes to be achieved, so that the Directorate of PSKBA should develop a specific strategy for its control. It is argued that top managers will choose to create an interactive managementcontrol system if a system is related to the gathering information about strategic uncertainty ${ }^{12}$. The personal involvement of top managers in defining the characteristics of internal control has a strong influence on providing an incentive to generate and share information ${ }^{12}$. To ensure that dispersed logistics personnel are competent and perform their duties in accordance with existing procedures, the Directorate of PSKBA could establish a team of supervisors as a means of communication, monitoring, and organizational learning. Focusing organizational attention on the interchange of information will interactively stimulate the learning process across all organizational components with strategic uncertainty ${ }^{12}$.

Based on the considerations in RD2, the resulting PQR formula is improving the competence of logistics 
personnel, and improving the effectiveness of monitoring and evaluation (P), through training and the formation of a supervisory team (Q), to optimize disaster-logistics-management activities at the Directorate of PSKBA (R). The CATWOE analysis and conceptual model are shown in Table 1 and Figure 3, respectively.

From the results of the discussion on the conceptual model for improving competency, and improving the effectiveness of monitoring and evaluation, the actors agree on several matters: the head of the logistics-utilization section and the head of the logistics-administration section will identify the criteria and requirements for the required competencies, and the identification results will be forwarded to the head of the sub-directorate for disaster logistics management; the head of the logistics-utilization section and the head of the logisticsadministration section will perform human resource mapping for the central and provincial officers to establish the database; the sub-directorate for disaster logistics management will establish a central mentoring team in accordance with the criteria and requirements, if instructed to do so by the director; and the sub-directorate for disaster logistics management will coordinate with the subdivision for administration in the framework used for proposing the activity budget.

\section{Conceptual Model 3}

Root definition number 3 (RD3) is related to improving procedures for the compilation of logistics reports. In compiling the disaster-logistics-inventory report, conducted by the Directorate of PSKBA, report verification is essential for maintaining the reliability of the carrying value of the final inventory. Managers should know the location of the inventory type, and everything related to inventory at certain times and locations by monitoring the inventory under its control ${ }^{13}$. The verification procedures for the regional logistics reports conducted by the Directorate of PSKBA have not been standardized in the official existing standard operating procedures (SOPs). The refinement of procedures in the context of the verification activities for this regional report is a step that must be done urgently by the Directorate of PSKBA, as it is understood that in order to achieve effective controls, an organization must develop control through policies and procedures, and management should review the policies and procedures when needed ${ }^{3}$. In addition, verification is also undertaken in order to identify the rupiah value of the inventory units recorded in the regional logistics report, so that it will be easy to track the difference between the regional and central reports.

Based on the considerations in RD3, the resulting PQR formula is refining the procedure for compiling disasterlogistics-inventory reports $(\mathrm{P})$, through the formulation of stages of activities in the process of compiling the disaster-logistics-inventory reports $(\mathrm{Q})$, to optimize the logistics management of disasters by the Directorate of PSKBA (R). The CATWOE analysis and conceptual model are shown in Table 1 and Figure 4, respectively.

From the results of the discussion on the conceptual model for improving the compilation procedure for logistics reports, the actors agree on several matters: the head of the logistics-administration section will improve coordination with the provincial logistics officers to raise awareness of the need for timely report submission; the head of the logistics-utilization section and the head of the logistics-administration section, together with the officers, will optimize the verification activity for the regional inventory report; and the sub-directorate of disaster logistics management will consider the database to be the documentation of the verification activities and the compilation of regional logistics inventory reports.

Table.1. CATWOE Analysis

Customer
Actor
$\begin{aligned} & \text { Director of PSKBA, head of disaster-logistics-governance sub-section, head of the logistics-administration } \\ & \text { section, head of the disaster-preparedness section, head of the TU subdivision and the logistics-management } \\ & \text { officer. }\end{aligned}$
Transformation
a. No formal understanding between the Directorate of PSKBA and local government on disaster logistics
management $\rightarrow$ A formal understanding between the Directorate of PSKBA and local government on disaster
logistics management.

Weltanschauung (Worldview)
Understanding will reduce the risk of problems due to the inequality between understanding and responsibility in disaster logistics management. Forming and training a supervisory team will streamline disaster-management activities, and monitoring and evaluation activities, and adequate procedures for compiling logistics reports will enhance disaster-logistics-management activities as they clarify the tasks, functions, and responsibilities of the parties involved. 
Environment $\quad$ Human resources, time, budget, and sectoral ego.

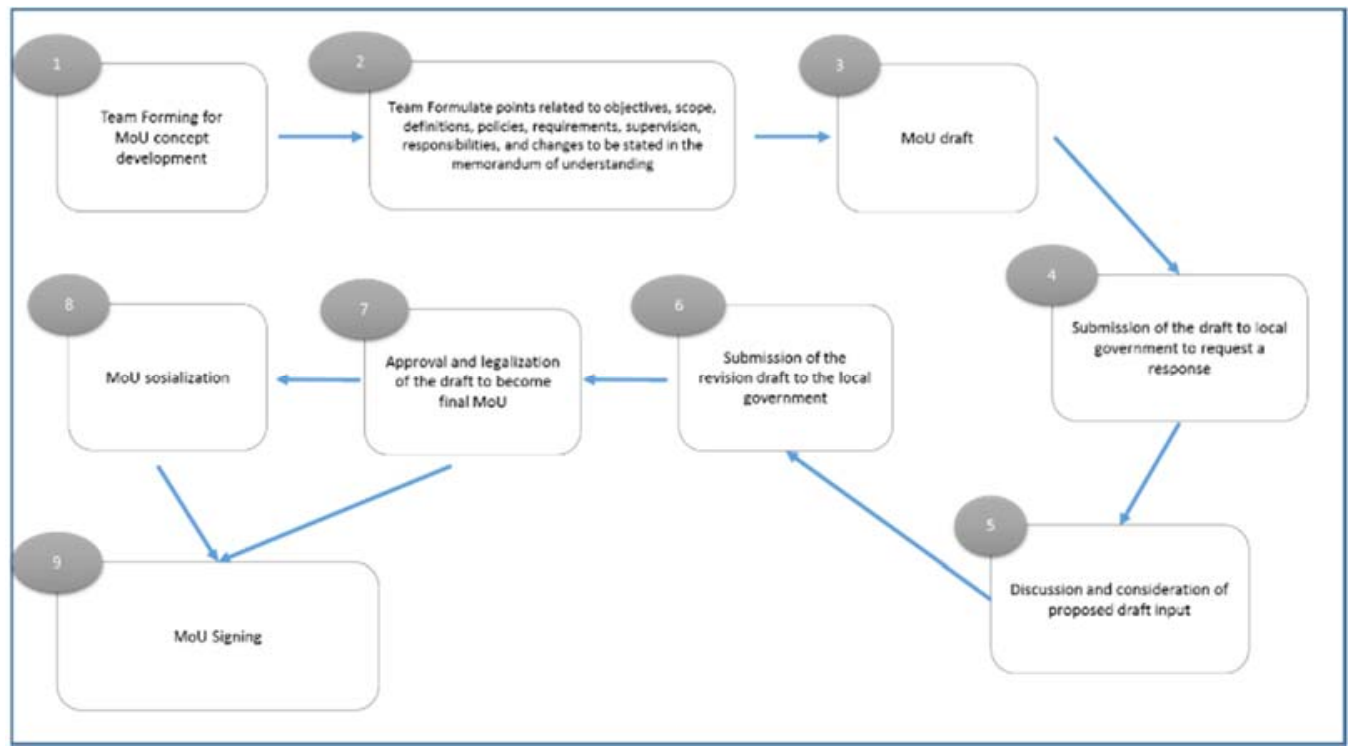

Figure.2. Conceptual Model for Strengthening the Local Government’s Understanding of Disaster Logistics Management

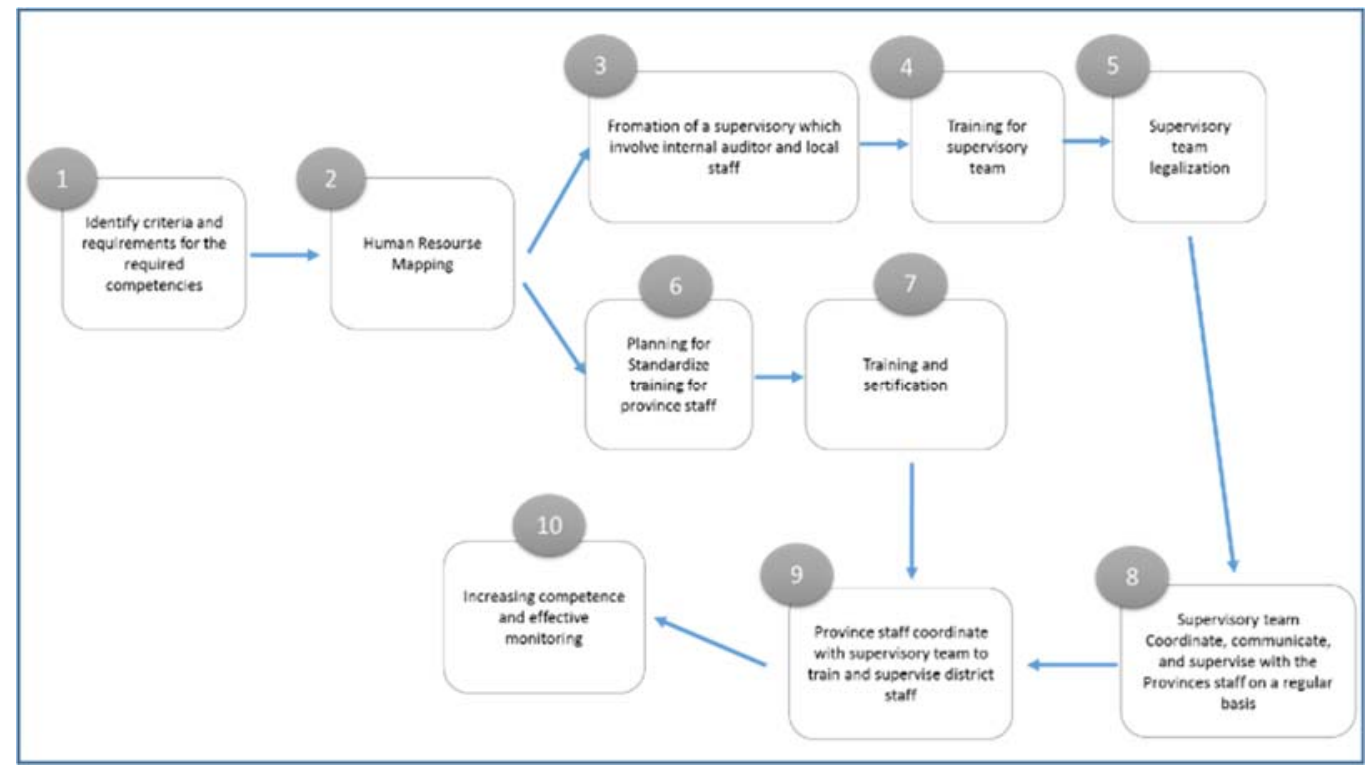

Figure.3. Conceptual Model for Improving Competency and the Effectiveness of Monitoring and Evaluation 


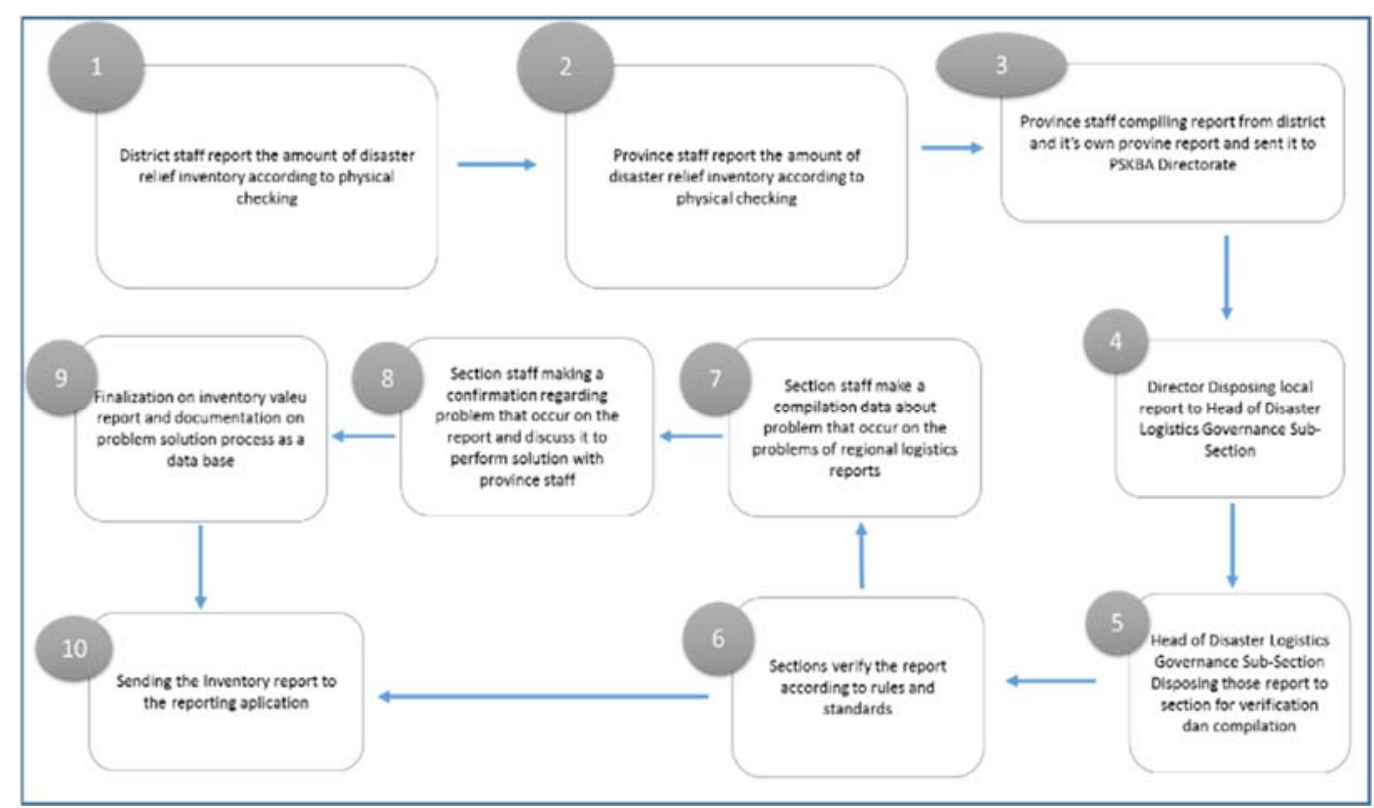

Figure.4. Conceptual Model for Improving Procedures for the Compilation of Logistics Reports

\section{CONCLUSION}

This research formulated some agreements that might be able to optimize the disaster-logistics-management process at the Directorate of PSKBA. First, the Directorate of PSKBA needs to develop and measure the early initiation of accepting the importance of building a common perception of developing disaster logistics management with the local government. Second, in order to improve the competence and knowledge of the logistics staff and the effectiveness of monitoring and evaluation activities, the Directorate of PSKBA needs to conduct standardized training in accordance with the competency requirements for disaster logistics management. In addition, the Directorate of PSKBA needs to establish a disaster-logistics-management supervisory team in order to provide guidance, supervision, and knowledge transfer so that disaster logistics management is conducted in accordance with the provisions, and the competence and knowledge of the logistics staff can be maintained. Lastly, the Directorate of PSKBA needs to increase effectiveness in compiling regional disaster reports. The improvements in effectiveness are achieved through verifying the logistics reports carefully and reliably, so that the Directorate of PSKBA is able to filter and solve the problems that occur on the local logistics reports before the final total logistics inventory is compiled into the financial statements.

\section{REFERENCES}

[1] BM Beamon, SA Kotleba. Inventory management support systems for emergency humanitarian relief operations in South Sudan. The International Journal of Logistics Management, 17(2) (2006) 187-212.

[2] TK Das, BS Teng. Trust, control, and risk in strategic alliances: An integrated framework. Organization Studies, 22(2) (2001) $251-283$.

[3] RR Moeller. Executive’s Guide to COSO Internal Control: Understanding and Implementing the New Framework. John Wiley \& Sons, New Jersey (2014).

[4] AS Thomas, LR Kopczak. From Logistics to Supply Chain Management: The Path Forward in the Humanitarian Sector. Fritz Institute, San Francisco, CA (2005).

[5] Badan Pemeriksa Keuangan Republik Indonesia. Laporan Hasil Pemeriksaan atas Sistem Pengendalian Intern Kementerian Sosial Tahun 2015 Nomor: 126.B/HP/XVI/05/2016. Badan Pemeriksa Keuangan Republik Indonesia, Jakarta (2016).

[6] A Cozzolino. Humanitarian logistics and supply chain management. In Humanitarian Logistics: Cross-sector Cooperation in Disaster Relief Management. Springer, Berlin (2012).

[7] EE Ozguven, K Ozbay. A secure and efficient inventory management system for disasters. Transportation Research Part C: Emerging Technologies, 29 (2013) 171-196.

[8] DC Whybark. Issues in managing disaster relief inventories. International Journal of Production Economics, 108(1) (2007) $228-235$.

[9] IN Pujawan, N Kurniati, NA Wessiani. Supply chain management for disaster relief operations: Principles and case studies. International Journal of Logistics Systems and Management, 5(6) (2009) 679-692.

[10] B Balcik, BM Beamon, CC Krejci, KM Muramatsu, M Ramirez. Coordination in humanitarian relief chains: Practices, challenges and opportunities. International Journal of Production Economics, 126 (1) (2010) 22-34.

[11] JJ Weygandt, PD Kimmel, DE Kieso. Accounting Principles, $12^{\text {th }}$ Edition. John Wiley \& Sons, New Jersey (2015).

[12] R Simons. The role of management control systems in creating competitive advantage: New perspectives. Accounting, Organizations and Society, 15(112) (1990) 127-143.

[13] RL Ballard. Methods of inventory monitoring and measurement. Logistics Information Management, 9(3) (1996) 11-18.

[14] JLC Cheng. Interdependence and coordination in organizations: A role-system analysis. The Academy of Management Journal, 26(1) (1983) 156-162.

[15] S Hardjosoekarto. Soft Systems Methodology (Metodologi Serba Sistem Lunak). UI Press, Jakarta (2012).

[16] R Simamora, A Halim. Faktor-faktor yang mempengaruhi pengelolaan aset pasca pemekaran wilayah dan pengaruhnya terhadap 
kualitas laporan keuangan pemerintah di Kabupaten Tapanuli Selatan. Jurnal Ekonomi dan Bisnis, 13(2) (2013) 47-61.

[17] KJ Ng'ang'a. An assessment of the factors influencing effectiveness of inventory control: Ministry of State for Provincial Administration and Internal Security, Nairobi-Kenya. International Journal of Business and Commerce, 3(1) 2013 33-53.

[18] Kementerian Sosial Republik Indonesia. Standar Operasional dan Prosedur Pengelolaan Logistik Bencana Alam Direktorat Perlindungan Sosial Korban Bencana Alam (PSKBA). Kementerian Sosial Republik Indonesia, Jakarta (2014). 